\title{
Cytotoxic Lipidic $\alpha$-amino Acids from the Zoanthid Protopalythoa variabilis from the Northeastern Coast of Brazil
}

\author{
Diego Veras Wilke, ${ }^{a}$ Paula Christine Jimenez, ${ }^{a}$ Claudia Pessoa, ${ }^{a}$ Manoel Odorico de Moraes, ${ }^{a}$ \\ Renata Mendonça Araújo, ${ }^{b}$ Wildson Max Barbosa da Silva, ${ }^{b}$ Edilberto Rocha Silveira, ${ }^{b}$ Otília Deusdênia \\ Loiola Pessoa, ${ }^{b}$ Raimundo Braz-Filho, ${ }^{b}$ Norberto Peporine Lopes ${ }^{c}$ and Letícia Veras Costa-Lotufo $* a$ \\ ${ }^{a}$ Departamento de Fisiologia e Farmacologia, Faculdade de Medicina, Universidade Federal do Ceará, \\ 60430-270 Fortaleza-CE, Brazil \\ ${ }^{b}$ Departamento de Química Orgânica e Inorgânica, Universidade Federal do Ceará, 60021-940 Fortaleza-CE, Brazil \\ ${ }^{c}$ Departamento de Física e Química, Faculdade de Ciências Farmacêuticas de Ribeirão Preto, \\ Universidade de São Paulo, 14040-903 Ribeirão Preto-SP, Brazil
}

\begin{abstract}
Dois $\alpha$-aminoácidos lipídicos $\mathbf{1 a}$ e $\mathbf{1 b}$ foram isolados do zoantídeo Protopalythoa variabilis através de fracionamento guiado pela atividade citotóxica. As estruturas foram determinadas por diferentes métodos espectroscópicos, tais como, RMN (ressonância magnética nuclear) ${ }^{1} \mathrm{He}^{13} \mathrm{C}$, IV (infravermelho) e espectrometria de massa de alta resolução (modo positivo). A atividade citotóxica dos extratos, das frações e 1a/1b foi avaliada in vitro através do teste do MTT contra quatro linhagens de células tumorais. Este achado tem implicações biológicas e químicas importantes para essa classe de compostos. Este é o primeiro relato de $\alpha$-aminoácidos lipídicos a partir de uma fonte natural, bem como de sua atividade citotóxica.
\end{abstract}

Two lipidic $\alpha$-amino acids $\mathbf{1 a}$ and $\mathbf{1 b}$ were isolated from the zoanthid Protopalythoa variabilis using a bioguided fractionation for cytotoxic activity. The structures of the metabolites were determined by spectroscopic methods, including NMR (nuclear magnetic resonance) ${ }^{1} \mathrm{He}{ }^{13} \mathrm{C}$, IR (infrared) and high resolution mass spectrometry (positive mode). The cytotoxic activity of the crude extract, as well as of the mixture of $\mathbf{1 a}$ and $\mathbf{1 b}$ were measured in vitro using the MTT assay for four human tumor cell lines. This finding has important biological and chemical implications for this type of compound. This is the first report of lipidic $\alpha$-amino acids from natural sources, as well as of their cytotoxic activity.

Keywords: Protopalythoa variabilis, lipidic $\alpha$-amino acids, cytotoxic activity

\section{Introduction}

Cnidarians produce a wide variety of compounds showing biological activities, such as antineoplastic, ${ }^{1}$ antioxidant, ${ }^{2}$ osteoporosis suppression $^{3}$ and anti-acetylcholinesterase. ${ }^{4}$ The most prolific ones are soft bodied sessile corals, such as gorgonians and zoanthids. ${ }^{5}$ Palytoxin, the most potent nonproteic toxin known, was first isolated from the zoanthid Palythoa toxica. ${ }^{6}$ Despite the interest of the chemical community due to the complexity of palytoxin molecule, it is a useful tool for probing cellular processes involving sodium as a second messenger, since it binds in $\mathrm{Na}^{+}$, $\mathrm{K}^{+}$-ATPase and transforms the pump into a channel permeable to monovalent cations. ${ }^{7,8}$ Moreover, new

\footnotetext{
*e-mail: lvcosta@secrel.com.br; lvcosta@ufc.br
}

steroids $^{9,10}$ and zoanthamine alkaloids, some of them with potent biological activity, ${ }^{11-15}$ were also isolated from species of the Zoanthidae family. Herein, in the continuing search to discover anticancer agents from marine sources ${ }^{16-19}$ we have investigated the zoanthid Protopalythoa variabilis Duerden 1898, an abundant cnidarian at the coast of Ceará State, northeast of Brazil.

In this paper the isolation and identification of two new lipidic $\alpha$-amino acids (1a and $\mathbf{1 b}$, Figure 1) from the zoanthid Protopalythoa variabilis is described. The literature describes the lipidic $\alpha$-amino acids (LAAs) as non-natural amino acids with long saturated, or unsaturated, aliphatic chains. Although highly lipophilic, these compounds still have polar behavior showing chemical and conformational characteristics of amino acids and peptides. $^{20-22}$ The potential use of LAAs in industries is 


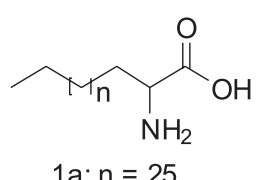

1b: $n=26$

Figure 1. Chemical structures of the lipidic $\alpha$-amino acids from Protopalythoa variabilis.

wide as lubricants, ${ }^{23}$ cosmetics,${ }^{24}$ polishes ${ }^{25}$ and surface improvers for ceramics. ${ }^{26}$ They are also medicinally useful. LAA amides with saturated or unsaturated long chain amines as well as LAA esters with saturated or unsaturated long chain alcohols, both have been synthesized. ${ }^{27}$ These compounds inhibited both porcine pancreatic ${ }^{28}$ and human platelet phospholipase A2 (PLA2) ${ }^{27}$ being potential antiinflammatory agents. LAAs and their oligomers have been suggested to work as a drug delivery system. ${ }^{29} \mathrm{~A}$ Lipid-Core-Peptide system has been designed and used as a combined adjuvant-carrier-vaccine system. ${ }^{30}$

\section{Results and Discussion}

In preliminary experiments, an aqueous- $\mathrm{MeOH}$ extract from Protopalythoa variabilis showed a potent cytotoxic activity. After a liquid-liquid partitioning, the biological activity was distributed among all fractions, but the hexane phase and the aqueous- $\mathrm{MeOH}$ residue demonstrated higher cytotoxicity as shown on Table 1. Comparative TLC (thin layer chromatography) showed some common spots in all fractions suggesting the presence of common compounds distributed among all fractions. Due to the higher activity and larger yield, the hexane fraction was chosen for further analytical separation procedures.

From the hexane fraction, a greasy solid named PV-Hex SII was obtained by successive solubilization/precipitation with $\mathrm{CH}_{3} \mathrm{CN} / \mathrm{H}_{2} \mathrm{O}$ at different proportions of solvents using different sample concentrations. Part of this solid was soluble in pyridine- $\mathrm{d}_{5}$, and after the solvent evaporation afforded the most active fraction designated PV-Hex-SIIS. This fraction showed a purple color when reacted with a $0.1 \%$ EtOH solution of nynhidrine on TLC plates. Its IR spectrum showed absorptions bands at 1633 and 1413 (-COO-) and 1644 and $1462\left(-\mathrm{NH}_{3}^{+}\right)$, characteristic of amino acids. The very simple ${ }^{1} \mathrm{H}$ NMR spectrum of PV-Hex SIIS exhibited only a signal at $\delta 3.57$ (br t, H-2), typical of a nitrogenated methine, an intense and broad signal at $\delta 1.27$, consistent with the long methylene moiety, and a broad triplet at $\delta 0.88$ characteristic of the terminal methyl of fatty chains. The ${ }^{13} \mathrm{C}$ NMR (CPD composite pulse decouplingand and DEPT 135) spectra revealed a signal at $\delta 54.7(\mathrm{C}-2)$ for the aminated $\alpha$-carbon, which in the HMQC (heteronuclear multiple quantum coherence) spectrum showed correlation with the signal at $\delta 3.57$ (H-2), highly suggestive of an $\alpha$-amino acid moiety, in addition to multiple carbon signals between $\delta 32.5$ to 23.3 (long chain methylenes) and a carbon signal at $\delta 14.6$ for the terminal methyl, suggesting the presence of a long alkyl chain. Despite the non observation of the carboxyl carbon in the ${ }^{13} \mathrm{C}$ NMR spectrum, these spectroscopic data suggested that the compounds of the PV-Hex SIIS were aliphatic amino acids. Indeed, the HR-ESI-TOF (positive ion mode) spectrum of this sample showed some cationizated ions at $\mathrm{m} / z$ 490.4566 $[\mathrm{M}+\mathrm{Na}]^{+}$indicating the molecular formula $\mathrm{C}_{30} \mathrm{H}_{61} \mathrm{NO}_{2}$ for 1a, while the ion peak at $\mathrm{m} / \mathrm{z} 504.4706$ $[\mathrm{M}+\mathrm{Na}]^{+}$was in agreement with the molecular formula $\mathrm{C}_{31} \mathrm{H}_{63} \mathrm{NO}_{2}$ for $\mathbf{1 b}$.

Additionally, the structures were confirmed after preparation of the methyl ester mixture $\left(\mathbf{1}^{\prime} \mathbf{\prime}^{\prime} \mathbf{1} \mathbf{b}^{\prime}\right)$ and its correspondent $\mathrm{N}$-acetyl methyl ester derivatives (1a"/1b"). The HMBC (heteronuclear multiple-bond connectivity) spectrum of the methyl ester clearly revealed a correlation for the amino hydrogens $(\delta 2.31)$ with the carbonyl carbon $(\delta 176.6)$, as well as with the methylene carbons at $\delta 30.8(\mathrm{C}-3)$ and $26.2(\mathrm{C}-4)$. Furthermore, a long-range coupling was also observed between the methyl ester group $(\delta 3.65$ ) with the carbonyl carbon. Further support to the structures of $\mathbf{1 a} / \mathbf{1} \mathbf{b}$ was obtained after acetylation of the methyl ester mixture 1a'/1b'. A signal at $\delta 2.19$ in the ${ }^{1} \mathrm{H}$ NMR spectrum of the acetylated methyl esters confirmed the $\mathrm{N}$-acetylation of both $\mathbf{1} \mathbf{a}^{\prime} / \mathbf{1} \mathbf{b}$ '. Therefore, the structures of $\mathbf{1 a} / \mathbf{1} \mathbf{b}$ could be unambiguously established.

\section{Conclusions}

There are three major points of chemical and biological implications that can be raised from these findings. First, there is no previous report on LAAs isolation from natural sources. Second, the number of carbon atoms for already known synthetic LAAs ranges from eight to twenty four ${ }^{22}$ what is different for the ones reported here. Third, the cytotoxic activity of LAAs has never been reported in the literature.

\section{Experimental}

\section{General Experimental Procedures}

IR spectrum (film on $\mathrm{NaCl}$ discs) was recorded using a Perkin-Elmer FT-IR 1000 spectrometer. NMR spectra were recorded on a Bruker Avance DRX-500 $\left(500 \mathrm{MHz}\right.$ for ${ }^{1} \mathrm{H}$ and $125 \mathrm{MHz}$ for ${ }^{13} \mathrm{C}$ ) spectrometer using pyridine- $d_{5}$ as solvent. Chemical shifts, given on the $\delta$ scale, were referenced to the residual undeuterated portion of the deuterated solvent 
for proton $\left(\delta_{\mathrm{H}} 8.74,7.58,7.22\right)$ and the center peak of the deuterated pyridine carbons $\left(\delta_{\mathrm{C}} 150.35,135.91,123.87\right)$. High resolution mass spectrometry were measured on a quadrupole-time of flight instrument (UltrOTOF-Q, Bruker Daltonics, Billerica, MA). The analyses were performed in positive ion ESI mode at a capillary voltage of $3400 \mathrm{~V}$ and $\mathrm{N}_{2}$ drying gas temperature of $180^{\circ} \mathrm{C}$. NaTFA $10 \mathrm{mM}$ was used as a standard for internal and external calibration. TLC was performed on precoated silica gel polyester sheets (kieselgel $60 \mathrm{~F}_{254}, 0.20 \mathrm{~mm}$, Merck). The compounds were detected by spraying with an EtOH solution of $0.1 \%$ nynhidrine.

\section{Biological Material Collection and Identification}

Protopalythoa variabilis colonies were manually collected at Paracuru beach (Paracuru, Ceará State, Brazil) at the intertidal zone during low tide. Voucher specimens ( $\mathrm{N}^{\circ}$ 000975), identified by Dr. Antonio Carlos Marques have been deposited at the Zoological Museum of the University of São Paulo (Museu de Zoologia, Universidade de São Paulo - MZUSP).

\section{Extraction and Bioguided Fractionation}

A large amount of colonies of Protopalythoa variabilis after collection was stored in plastic coolers containing crushed ice and immediately transported to the laboratory. The contaminants (little rock pieces and algae specimens) were removed from the colonies. The material was weighted $(11.3 \mathrm{~kg})$, blended and soaked with $\mathrm{MeOH}(2 \times 5 \mathrm{~L})$ during $48 \mathrm{~h}$ at $10{ }^{\circ} \mathrm{C}$. After filtration, the $\mathrm{MeOH}$ extract was evaporated under reduced pressure at $45^{\circ} \mathrm{C}$ to approximately $400 \mathrm{~mL}$ of an aqueous suspension (named PV-HE) to which an equal amount of $\mathrm{MeOH}$ was added and liquid partitionated with hexane, followed by partition with $\mathrm{CH}_{2} \mathrm{Cl}_{2}$ and finally with EtOAc. After solvent evaporation, $1.6 \mathrm{~g}$ of PV-Hex, $178.2 \mathrm{mg}$ of PV-CH${ }_{2} \mathrm{Cl}_{2}, 1.2 \mathrm{~g}$ of PV-EtOAc and $41.4 \mathrm{mg}$ of $\mathrm{PV}-\mathrm{MeOH} / \mathrm{H}_{2} \mathrm{O}$ extracts were obtained. All fractions were biologically assayed showing cytotoxicity, but PV$\mathrm{Hex}$ and $\mathrm{PV}-\mathrm{MeOH} / \mathrm{H}_{2} \mathrm{O}$ were the most actives (see data on Table 1). Due to its higher amount PV-Hex was chosen for further purification through high performance liquid chromatography (HPLC) analysis, but this procedure was not successful due to the poor solubility of this fraction. The treatment of PV-Hex with a mixture of $\mathrm{CH}_{3} \mathrm{CN} / \mathrm{H}_{2} \mathrm{O}$ (1:1) yielded an inactive precipitate $(548 \mathrm{mg})$, while the soluble part (PV-Hex S, $680 \mathrm{mg}$ ) retained and improved the cytotoxic activity. The PV-Hex S was only partially soluble in $\mathrm{CH}_{3} \mathrm{CN} / \mathrm{H}_{2} \mathrm{O}$ (8:2), being the stronger activity observed for the insoluble residue (PV-Hex SII, $90 \mathrm{mg}$ ). The solubility of this solid was systematically investigated using deuterated solvents, and only the soluble fraction obtained in pyridine- $d_{5}$ (PV-Hex SIIS, $26.7 \mathrm{mg}$ ) revealed a much stronger cytotoxic activity than all other tested fractions (see Table 1). ${ }^{1} \mathrm{H}$ and ${ }^{13} \mathrm{C}$ NMR analysis of PV-Hex SIIS revealed it to be a mixture of $\mathbf{1 a}$ and $\mathbf{1 b}$, as confirmed by HRESIMS (high resolution electrospray ionization mass spectrometry).

Lipidic $\alpha$-amino acids $(\mathbf{l} \boldsymbol{a} / \mathbf{l} \boldsymbol{b})$ : Brown wax, IR $v \mathrm{~cm}^{-1}$ 3390, 2924, 2853, 1644, 1633, 1462, 1413; ${ }^{1} \mathrm{H}$ NMR (pyridine- $\mathrm{d}_{5}, 500 \mathrm{MHz}$ ) 0.88 (br s, H-30/H-31), 1.27 (br s, methylene hidrogens), 3.57 (br s, H-2); ${ }^{13} \mathrm{C}$ NMR (pyridine-d $\left.\mathrm{d}_{5}, 125 \mathrm{MHz}\right) 54.7$ (C-2), $32.4(\mathrm{C}-28), 30.4$

Table 1. Cytotoxic activity of PV-HE, its derivative fractions and PV-Hex-SIIS on tumor cell lines evaluated by the MTT, assay for $72 \mathrm{~h}$ incubation. Data are presented as $\mathrm{IC}_{50}$ with their CI $95 \%$ values by non-linear regression. Experiments were performed in triplicate. N.T. not tested

\begin{tabular}{|c|c|c|c|c|}
\hline \multirow{2}{*}{ Samples } & \multicolumn{4}{|c|}{$\mathrm{IC}_{50}(\mu \mathrm{g} / \mathrm{mL}) \mathrm{CI} 95 \%$} \\
\hline & HL-60 & HCT-8 & SF-295 & MDA-MB-435 \\
\hline Doxorubicin & $\begin{array}{c}0.02 \\
0.01-0.02\end{array}$ & $\begin{array}{c}0.04 \\
0.03-0.05\end{array}$ & $\begin{array}{c}0.24 \\
0.17-0.36\end{array}$ & $\begin{array}{c}0.48 \\
0.34-0.66\end{array}$ \\
\hline PV-HE & $\begin{array}{c}0.40 \\
0.27-0.59\end{array}$ & $\begin{array}{c}0.36 \\
0.09-1.38\end{array}$ & $\begin{array}{c}4.24 \\
3.25-5.52\end{array}$ & $\begin{array}{c}0.73 \\
0.48-1.09\end{array}$ \\
\hline $\mathrm{PV}-\mathrm{MeOH} / \mathrm{H}_{2} \mathrm{O}$ & $\begin{array}{c}0.76 \\
0.62-0.94\end{array}$ & $\begin{array}{c}0.40 \\
0.32-0.49\end{array}$ & $\begin{array}{c}0.49 \\
0.40-0.59\end{array}$ & $\begin{array}{c}0.085 \\
0.02-0.41\end{array}$ \\
\hline PV-EtOAc & $\begin{array}{c}2.94 \\
1.94-4.46\end{array}$ & $\begin{array}{c}2.25 \\
1.26-4.02\end{array}$ & $\begin{array}{c}1.85 \\
1.29-2.65\end{array}$ & $\begin{array}{c}1.42 \\
1.08-1.87\end{array}$ \\
\hline $\mathrm{PV}-\mathrm{CH}_{2} \mathrm{Cl}_{2}$ & $\begin{array}{c}5.43 \\
4.86-6.07\end{array}$ & $\begin{array}{c}2.67 \\
2.19-3.24\end{array}$ & $\begin{array}{c}2.95 \\
2.68-3.25\end{array}$ & $\begin{array}{c}2.82 \\
2.40-3.29\end{array}$ \\
\hline PV-Hex & $\begin{array}{c}0.43 \\
0.39-0.47\end{array}$ & $\begin{array}{c}0.24 \\
0.22-0.27\end{array}$ & $\begin{array}{c}0.29 \\
0.25-0.33\end{array}$ & $\begin{array}{c}0.38 \\
0.34-0.43\end{array}$ \\
\hline PV-Hex SIIS (1a/1b) & $\begin{array}{c}0.13 \\
0.12-0.14\end{array}$ & $\begin{array}{c}0.05 \\
0.05-0.06\end{array}$ & $\begin{array}{c}0.07 \\
0.06-0.08\end{array}$ & N.T. \\
\hline
\end{tabular}


(C-5/C-27), 29.9 (C-3), 26.8 (C-4), 23.3 (C-29/C-30), 14.6 (C-30/C-31); HR-ESI-TOFMS (1a) $\mathrm{m} / \mathrm{z} 490.4566$ $[\mathrm{M}+\mathrm{Na}]^{+}$(calcd. for $\left.\mathrm{C}_{30} \mathrm{H}_{61} \mathrm{NO}_{2} \mathrm{Na}, 490.4599\right) ;(\mathbf{1 b}) \mathrm{m} / \mathrm{z}$ $504.4706[\mathrm{M}+\mathrm{Na}]^{+}$(calcd. for $\mathrm{C}_{31} \mathrm{H}_{63} \mathrm{NO}_{2} \mathrm{Na}, 504.4756$ ).

Methylation of $\mathbf{1} \boldsymbol{a} / \mathbf{1} \boldsymbol{b}$ : An aliquot (4.0 mg) of the lipidic $\alpha$-amino acids $(\mathbf{1 a} / \mathbf{1 b})$ was dissolved in $\mathrm{MeOH}$ with catalytic amounts of $\mathrm{HCl}$, and stirred under reflux during 4 h. Usual work-up afforded 1a'/1 b' (4.2 mg). ${ }^{1} \mathrm{H}$ NMR (pyridine- $\left.\mathrm{d}_{5,} 500 \mathrm{MHz}\right) 0.93$ (t, $J=6.45 \mathrm{~Hz}, \mathrm{H}-30 / \mathrm{H}-31$ ), 1.32 (br s, methylene hydrogens), $2.31\left(\mathrm{NH}_{2}\right), 3.66$ (br s, $\mathrm{H}-2), 3.65\left(\mathrm{~s}, \mathrm{OCH}_{3}\right) ;{ }^{13} \mathrm{C}$ NMR (pyridine-d $\mathrm{d}_{5}, 125 \mathrm{MHz}$ ) 176.6 (C-1), 52.1 (C-2), 33.2 (C-28), 30.8-23.8 (C-3/C-29), $14.6(\mathrm{C}-30 / \mathrm{C}-31)$.

Acetylation of $1 a^{\prime} / 1 b^{\prime}$ : This material was dissolved in a mixture of pyridine/acetic anhydride 1:2 $(1 \mathrm{~mL})$ and stirred for $24 \mathrm{~h}$ at room temperature. After this, the reaction mixture was neutralized with a solution of $\mathrm{HCl} 1 \mathrm{~mol} \mathrm{~L}^{-1}$ (4 drops) and extracted with $\mathrm{CH}_{2} \mathrm{Cl}_{2}$ (4 x $10 \mathrm{~mL}$ ). The $\mathrm{CH}_{2} \mathrm{Cl}_{2}$ layer was evaporated under reduced pressure to yield $\mathbf{1 a}$ "/1 $\mathbf{1 b}$ "

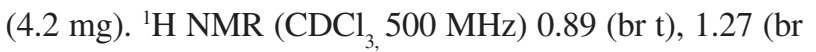
$\mathrm{s}$, methylene hydrogens), 2.19 (s), $3.68\left(\mathrm{~s}, \mathrm{OCH}_{3}\right)$.

\section{Cytotoxic assay}

The cytotoxic potential of the extract and of all derived fractions was evaluated against four tumor cell lines (National Cancer Institute, Bethesda, MD, USA): HCT-8 (human colon), MDA-MB-435 (melanoma), SF295 (CNS glioblastoma) and HL-60 (leukemia) using the 3-(4,5-dimethyl-2-thiazolyl)-2,5-diphenyl-2H-tetrazolium (MTT) assay described by Mosmann ${ }^{31}$ after $72 \mathrm{~h}$ incubation. Doxorubicin was used as positive control.

\section{Acknowledgment}

The authors would like to acknowledge the financial support in the form of grants and/or fellowships from the following Brazilian agencies: CNPq, FINEP and Institute Claude Bernard (InCB). The authors are grateful to Antonio Carlos Marques, from University of São Paulo for taxonomic identification of the zoanthid. The technical assistance of Silvana França is gratefully acknowledged.

\section{Supporting Information Available}

Supplementary information for compounds $\mathbf{1 a}$ and $\mathbf{1 b}$ is available free of charge as PDF file at http://jbcs.sbq.org.br.

\section{References}

1. Pettit, G.; Fuji, Y.; J. Nat. Prod. 1982, 45, 640.

2. Dunlap, W.C.; Yamamoto, Y.; Comp. Biochem. Physiol. 1995, $112 B, 105$.

3. Yamaguchi, K.; Yada, M.; Tsuji, T.; Kuramoto, M.; Uemura, D.; Biol. Pharm. Bull. 1999, 22, 920.

4. Turk, T.; Macek, P.; Suput, D.; Toxicon 1995, 33, 133.

5. Harper, M.K.; Bugni, T.S.; Copp, B.R.; James, R.B.; Lindsay, B.S.; Richardson, A.D.; Marine Chemical Ecology. In the McClintock, JB \& Baker BJ eds.; Boca Raton, Florida, 2001.

6. Moore, R.E.; Scheuer, P.J.; Science 1971, 172, 495.

7. Wang, D.Z.; Mar. Drugs 2008, 6, 349.

8. Jha, R.K.; Zi-rong, X.; Mar. Drugs 2004, 2, 123.

9. Guerriero, A.; Traldi, P.; Pietra. F.; J. Chem. Soc., Chem. Commun. 1986, 40.

10. Suksamrarn, A.; Jankam, A.; Tarnchompoo, B.; Putchakarn, S.; J. Nat. Prod. 2002, 65, 1194.

11. Behenna, D.C.; Stockdill, J.L.; Stoltz, B.M.; Angew. Chem. 2008, 47, 2365.

12. Daranas, A.H.; Fenandez, J.J.; Gavin, J. A.; Norte, M.; Tetrahedron 1999, 55, 5539.

13. Rao, C.B.; Anjaneyula, A.S.R. Sarma, N.S.; Venkatateswarlu. Y.; J. Am. Chem. Soc. 1984, 106, 7983.

14. Fattorusso, E.; Romano, A.; Taglialatela-Scafati, O.; Achmad, M.J.; Bavestrello, G.; Cerrano, C.; Tetrahedron Lett. 2008, 49, 2189.

15. Villar, R.M.; Gil-Longo, J.; Daranas, A.H.; Souto, M.L.; Fernández, J.J.; Peixinho, S.; Barral, M.A.; Santafé, G.; Rodríguez, J.; Jiménez, C.; Bioorg. Med. Chem. 2003, 11, 2301.

16. Jimenez, P.C.; Fortier, S.C.; Lotufo, T.M.C.; Pessoa, C.; Moraes, M.E.A.; Moraes, M.O.; Costa-Lotufo, L.V.; J. Exp. Mar. Biol. Ecol. 2003, 4040, 1.

17. Takeara, R.; Lopes, J. L. C.; Lopes, N. P.; Jimenez, P. C.; CostaLotufo, L. V.; Quim. Nova, 2007, 30, 1179.

18. Takeara, R.; Jimenez, P. C.; Costa-Lotufo, L. V. ; Lopes, J. L. C.; Lopes, N. P.; J. Braz. Chem. Soc. 2007, 18, 1054.

19. Jimenez, P.C.; Wilke, D.V.; Takeara, R.; Lotufo, T.M. C.; Pessoa, C.; Moraes, M.O.; Lopes, N.P.; Costa-Lotufo, L.V.; Comp. Biochem. Physiol. 2008, 151, 391.

20. Roberts, D.C.; Vellaccio, F.; In: Gross E, Meinhofer J. eds.; Academic Press: New York, 1983.

21. Williams, R.M.; Synthesis of opticaly active alpha-amino acids. Pergamon Press, Oxford, 1989.

22. Kokotos, G.; Martin, V.; Constantinou-Kokotou, V.; Gibbons, W.A.; Amino Acids 1996, 11, 329.

23. Takino, H.; Sagawa, K.; Kitamura, N.; Kilahara, M.; Jpn. Kokai Tokkyo Koho 62,151,495 1987 (CA 107:220318c)

24. Kitamura. N.; Sagawa, K.; Takehara, M',; Jpn. Kokai Tokkyo Koho 62 04,211 1987 (CA 106:182464s). 
25. Sagawa, K.; Takehara, M.; Jpn. Kokai Tokkyo Koho 62 30,171 1987a (CA 107:79672e).

26. Sagawa, K.; Takehara, M.; Jpn. Kokai Tokkyo Koho 62 65,964 1987b (CA 107:63607b).

27. Kokotos, G.; Constantinou-Kokotou, V.; Noula, C.; Nicolaou, A.; Gibbons, W.A.; Int. J. Peptide. Protein. Res. Ther. 1996, 48, 160.

28. Nicolaou, A.; Kokotos, G.; Constantinou-Kokotou, V.; York, J.; Gibbons, W.A.; Biochem. Soc. Trans. 1995, 23, 614S.
29. Toth, I.; J. Drug. Targeting. 1994, 2, 217.

30. Toth, I.; Danton, M.; Flinn, N.; Gibbons, W.A.; Tetrahedron 1993, 34, 3925.

31. Mosmann, T.; J. Immunol. Met. 1983, 65, 55.

Received: August 12, 2008 Web Release Date: August 20, 2009

FAPESP helped in meeting the publication costs of this article. 


\section{Cytotoxic Lipidic $\alpha$-amino Acids from the Zoanthid Protopalythoa variabilis from the Northeastern Coast of Brazil}

Diego Veras Wilke, ${ }^{a}$ Paula Christine Jimenez, ${ }^{a}$ Claudia Pessoa, ${ }^{a}$ Manoel Odorico de Moraes, ${ }^{a}$ Renata Mendonça Araújo, ${ }^{b}$ Wildson Max Barbosa da Silva, ${ }^{b}$ Edilberto Rocha Silveira, ${ }^{b}$ Otília Deusdênia Loiola Pessoa, ${ }^{b}$ Raimundo Braz-Filho, ${ }^{b}$ Norberto Peporine Lopes ${ }^{c}$ and Letícia Veras Costa-Lotufo $* a$

${ }^{a}$ Departamento de Fisiologia e Farmacologia, Faculdade de Medicina, Universidade Federal do Ceará, 60430-270 Fortaleza-CE, Brazil

${ }^{b}$ Departamento de Química Orgânica e Inorgânica, Universidade Federal do Ceará, 60021-940 Fortaleza-CE, Brazil

'Departamento de Física e Química, Faculdade de Ciências Farmacêuticas de Ribeirão Preto, Universidade de São Paulo, 14040-903 Ribeirão Preto-SP, Brazil

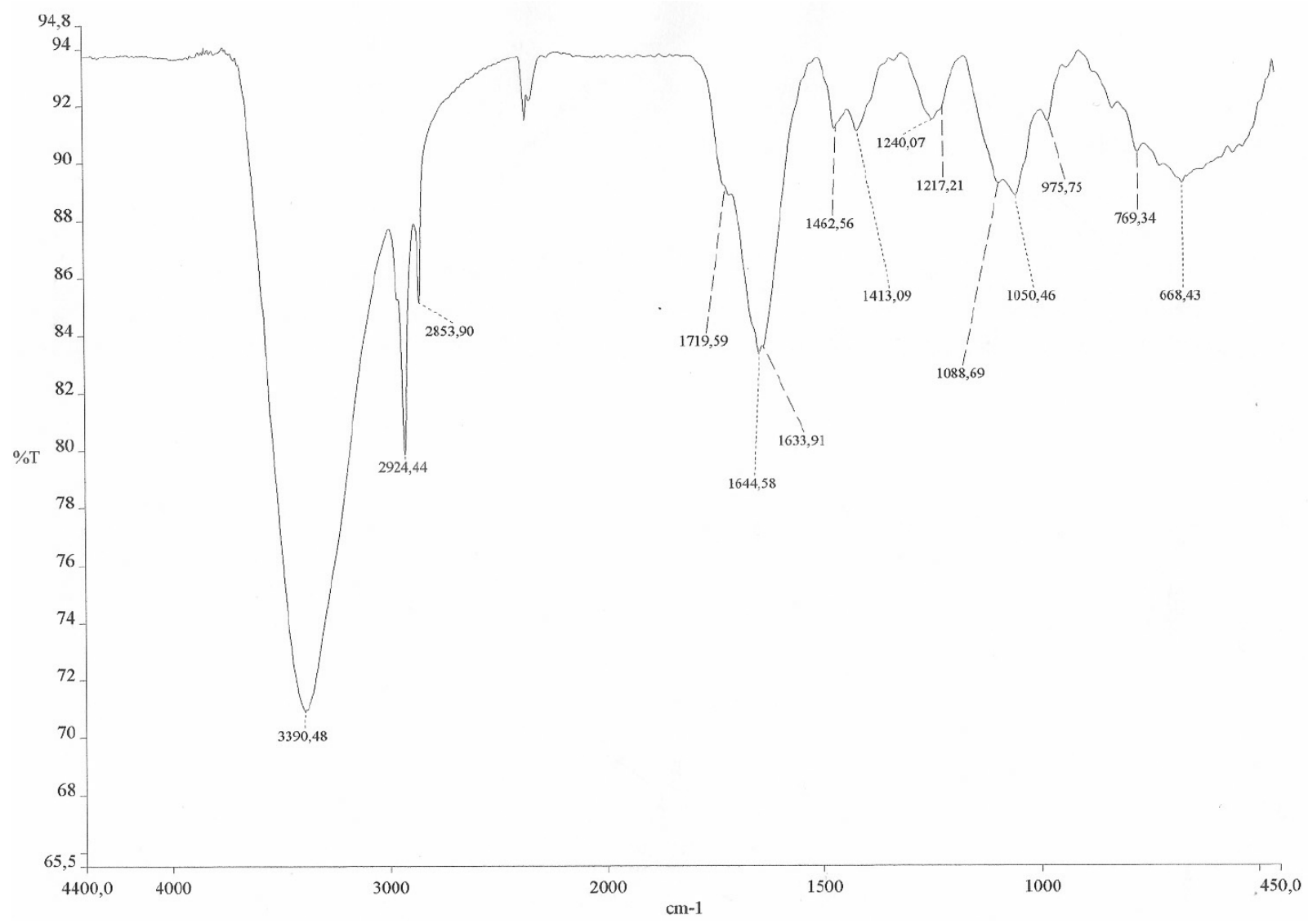

Figure S1. IR spectrum of mixture of two lipidic $\alpha$-amino acids (1a and $\mathbf{1 b}$ )

*e-mail:1vcosta@secrel.com.br; lvcosta@ufc.br 
言<smiles>[Te]C1CC1</smiles>

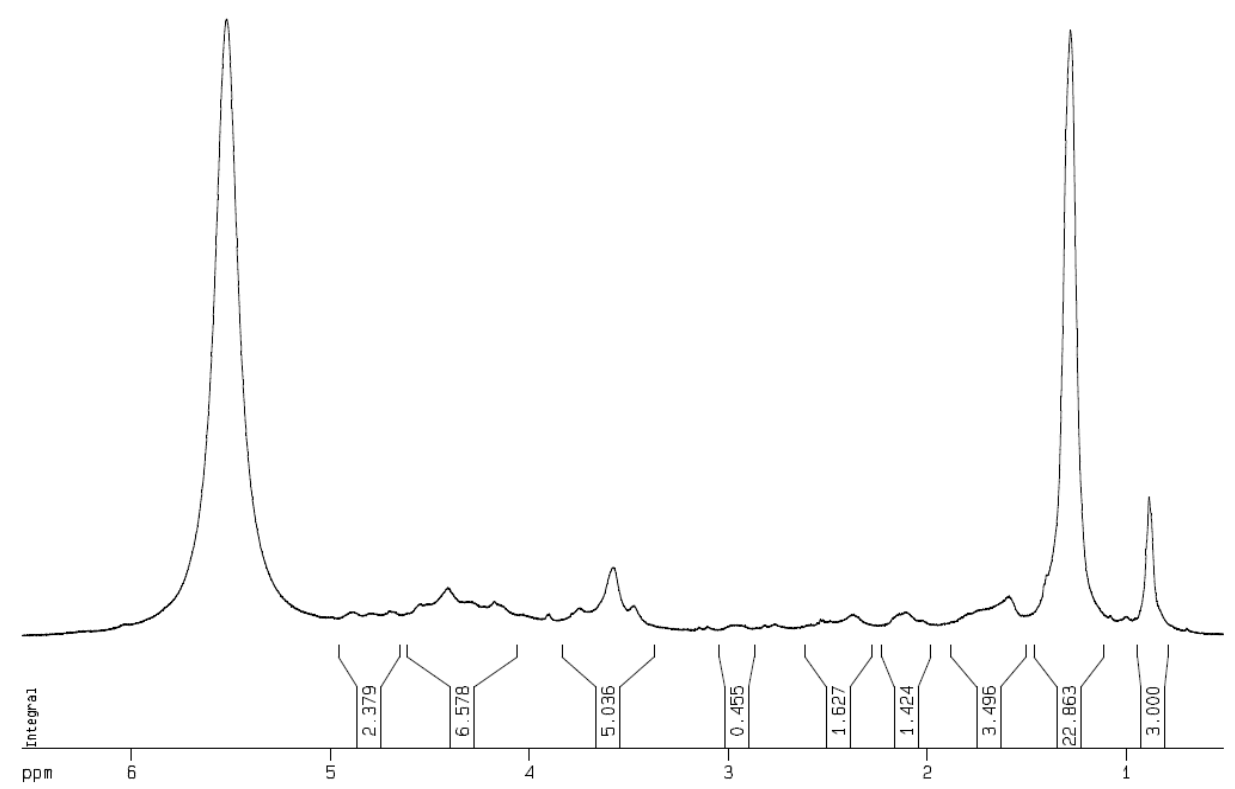

Figure S2. ${ }^{1} \mathrm{H}$ NMR spectrum ( $\left.500 \mathrm{MHz}, \mathrm{C}_{5} \mathrm{D}_{5} \mathrm{~N}\right)$ of a mixture of two lipidic $\alpha$-amino acids (1a and $\mathbf{1 b}$ )

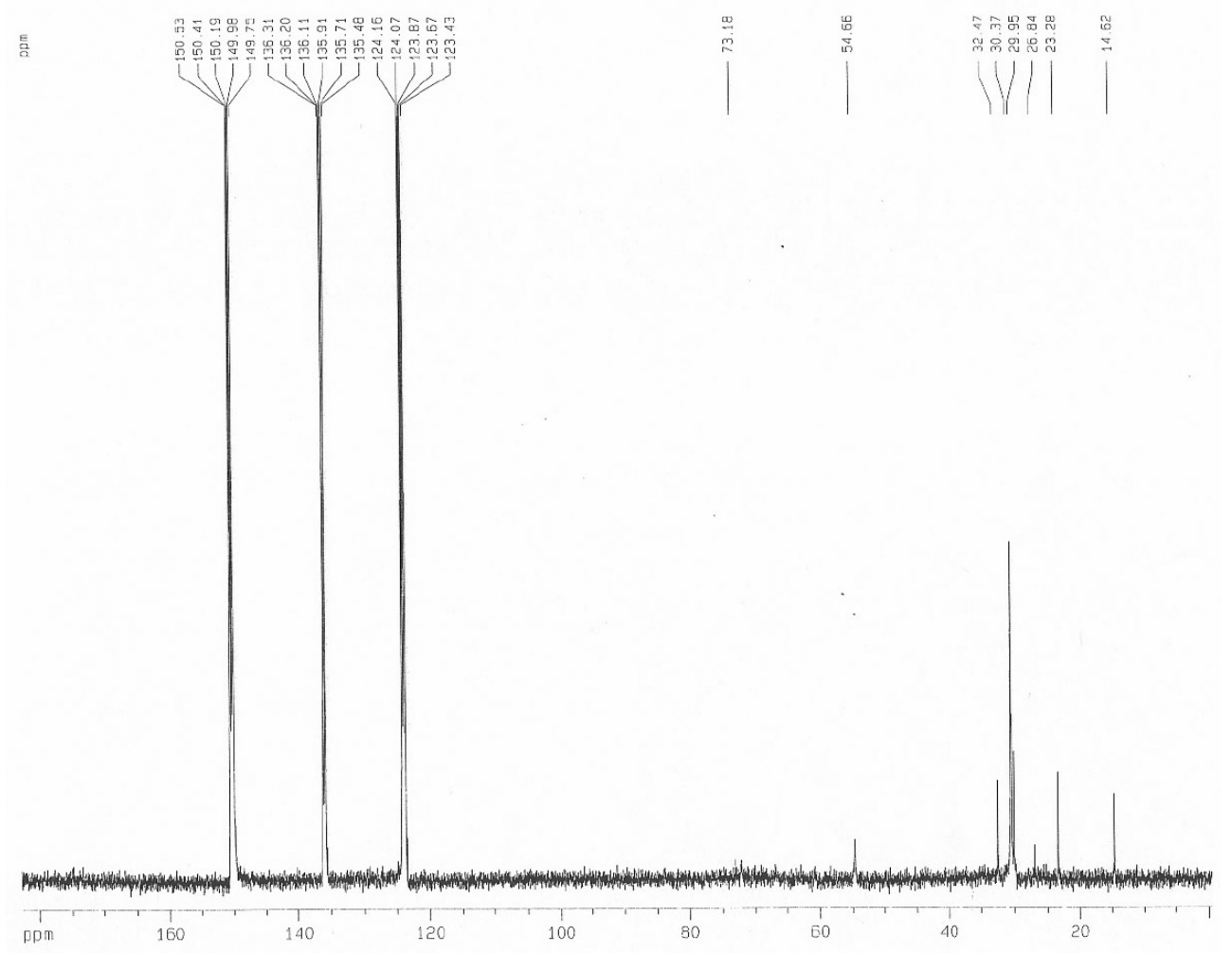

Figure S3. ${ }^{13} \mathrm{C}$ NMR spectrum $\left(125 \mathrm{MHz}, \mathrm{C}_{5} \mathrm{D}_{5} \mathrm{~N}\right)$ of a mixture of two lipidic $\alpha$-amino acids (1a and $\left.\mathbf{1 b}\right)$ 


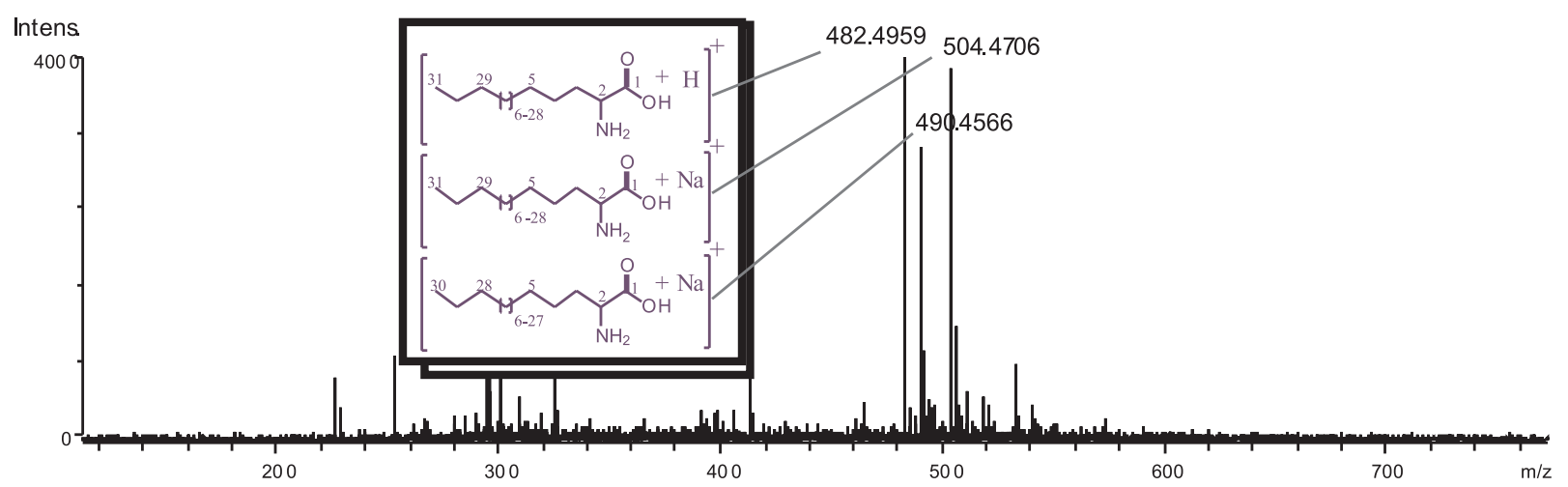

Figure S4. HRESI-MS spectrum of a mixture of two lipidic $\alpha$-amino acids $(\mathbf{1 a}$ and $\mathbf{1 b})$. The major ions: $\mathbf{1 a} \mathrm{m} / z 490.4566[\mathrm{M}+\mathrm{Na}]^{+}\left(\mathrm{calc}^{2}\right.$. for $\mathrm{C}_{30} \mathrm{H}_{61} \mathrm{NO}_{2} \mathrm{Na}$, 490.4599); $\mathbf{1 b} \mathrm{m} / z$ 482.4959[M+H]+ (calc. for $\mathrm{C}_{31} \mathrm{H}_{64} \mathrm{NO}_{2}, 482.4936$ ); $\mathbf{1 b} \mathrm{m} / z .504 .4706[\mathrm{M}+\mathrm{Na}]^{+}$(calc. for $\mathrm{C}_{31} \mathrm{H}_{64} \mathrm{NO}_{2} \mathrm{Na}, 504.4756$ ).

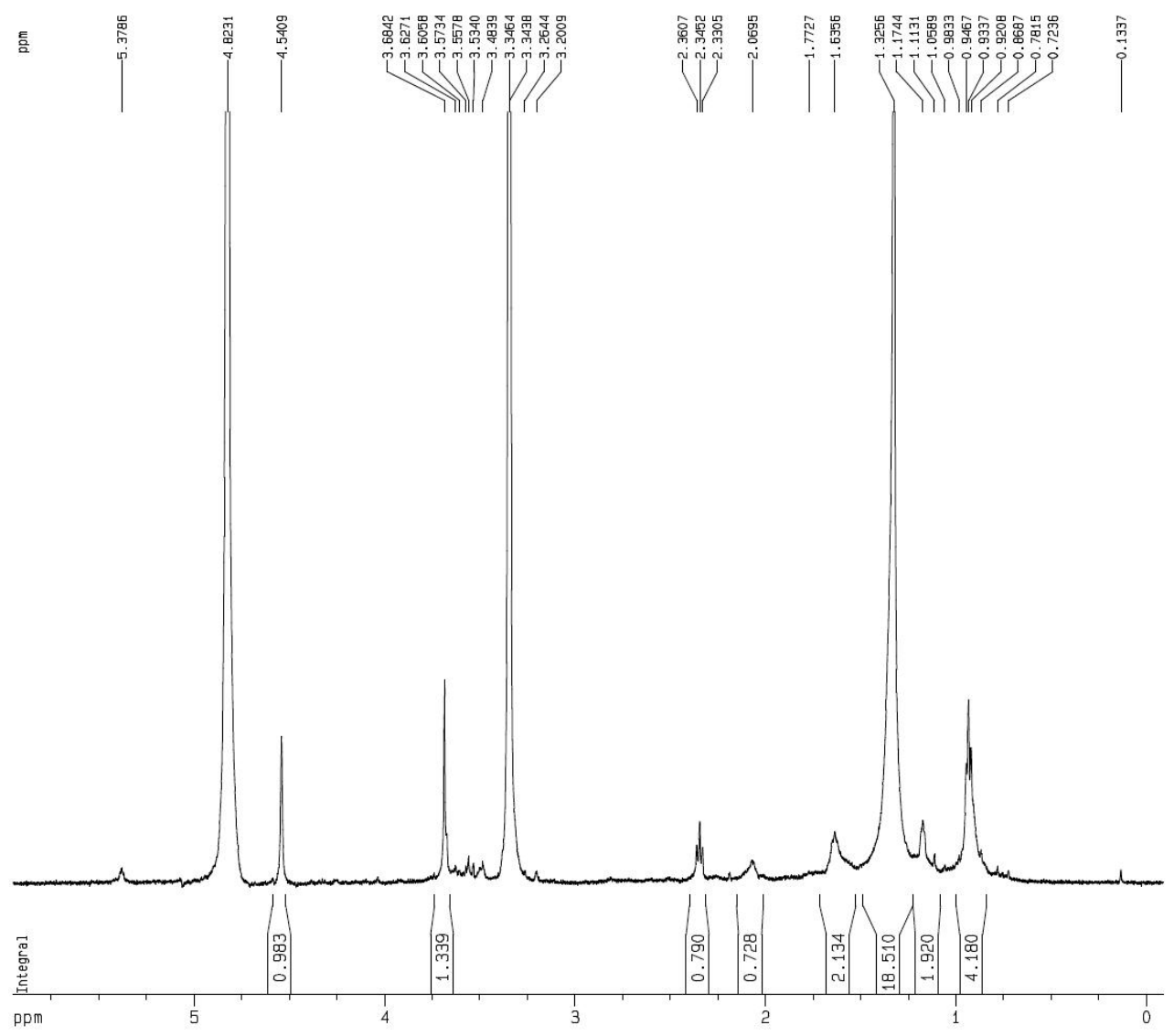

Figure S5. 'H NMR spectrum (500 MHz, MeOD) of a methyl ester mixture (19'/1/b') 


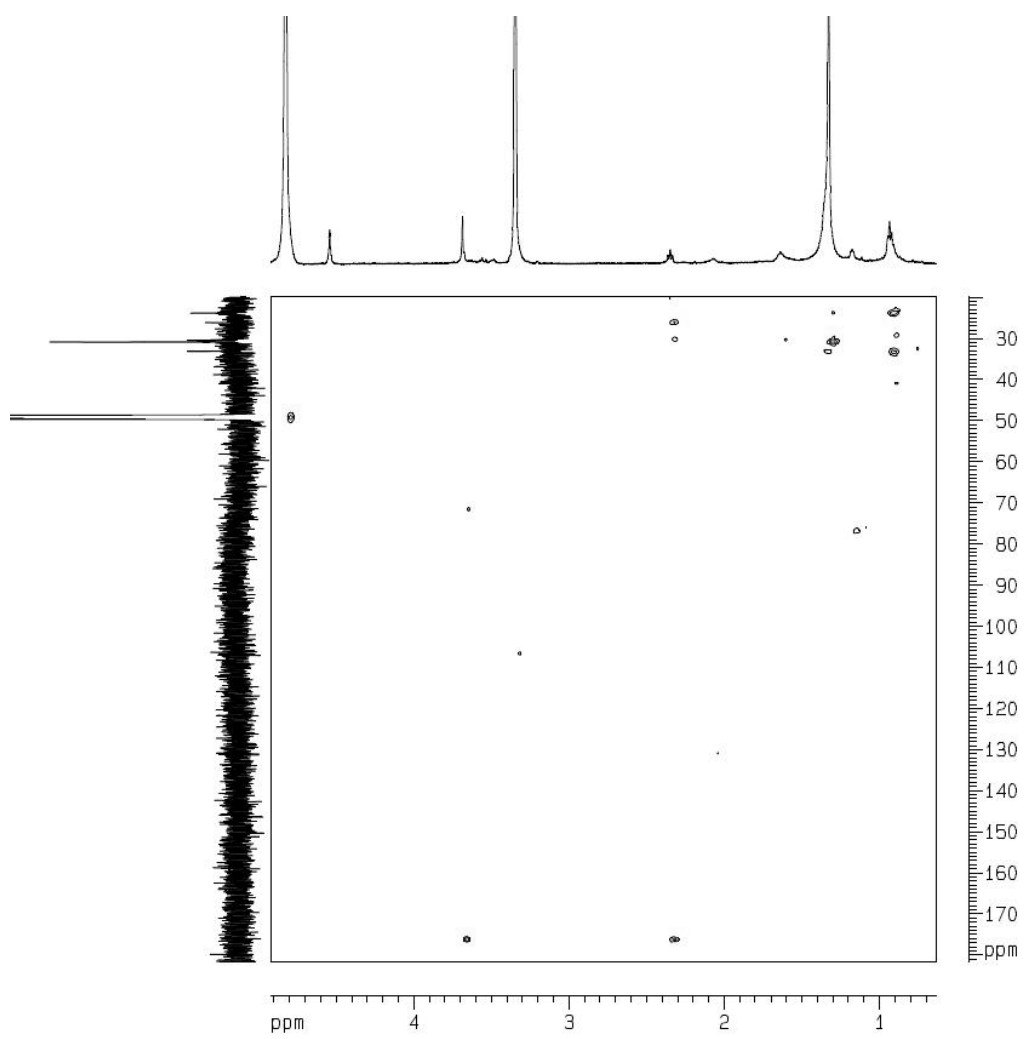

Figure S6. HMBC spectrum (500 MHz, MeOD) of methyl ester derivatives (1a'/1b')

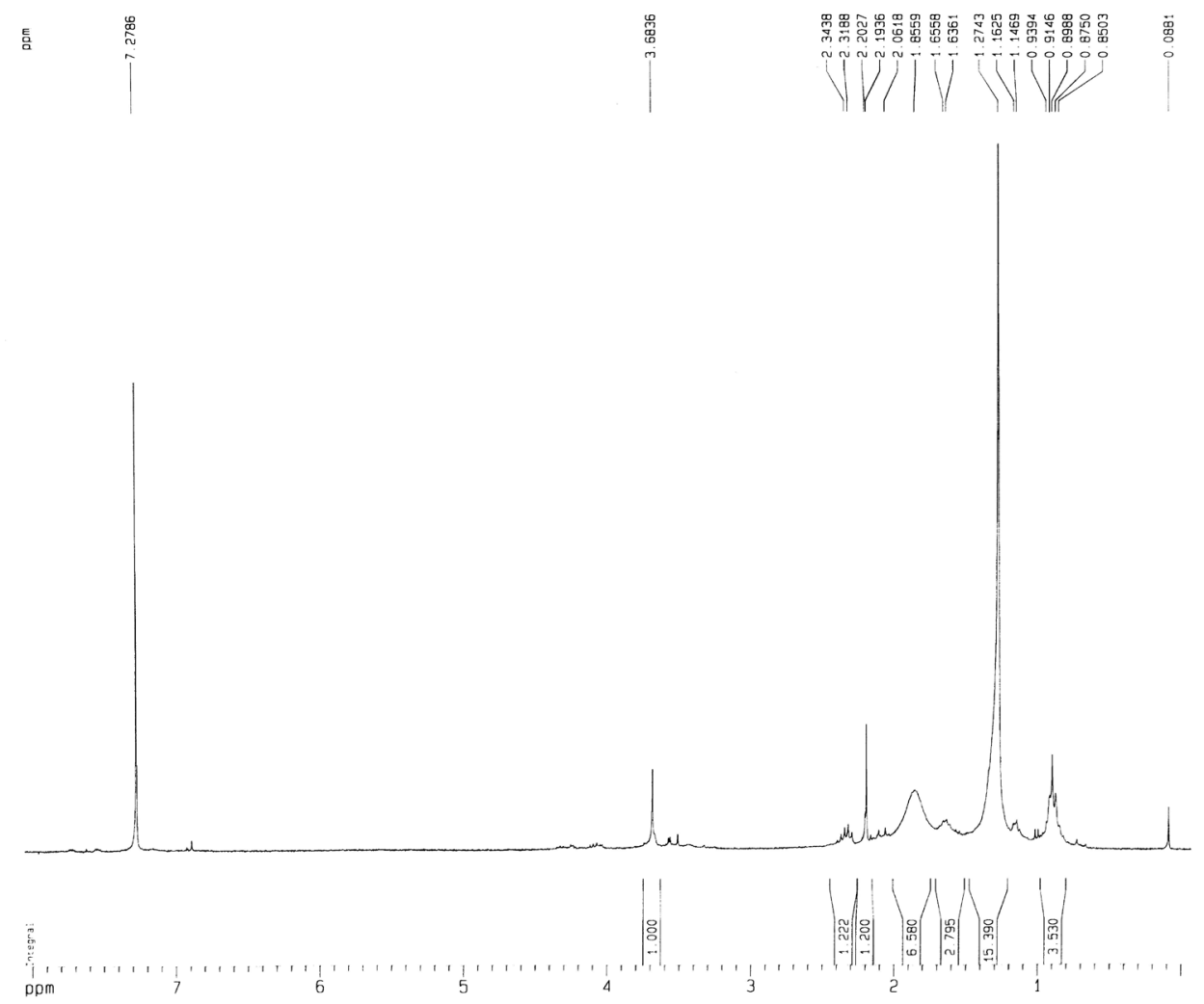

Figure S7. 'H NMR spectrum (500 MHz, $\mathrm{CDCl}_{3}$ ) of $\mathrm{N}$-acetyl methyl ester derivatives (1a"/1b") 